\title{
Note on consumption of fox bait by alien raccoons in eastern Hokkaido, Japan
}

\author{
Hiiragi Arisawa, Kohji Uraguchi, Hirokazu Kouguchi \& Tatsuo Oshida*
}

ABSTRACT. Alveolar echinococcosis is a zoonosis caused by tapeworm, Echinococcus multilocularis. The red fox (Vulpes vulpes) is its principle definitive host. Effective decrease in E. multilocularis prevalence is a result of baiting red foxes with the anthelmintic praziquantel. Recently, introduced raccoons (Procyon lotor) are increasing in Hokkaido, Japan. If they frequently consume fox bait, the baiting campaign may not be effective on red foxes. With camera trap, we examined seasonal consumption of fox bait by raccoons in Memuro, Tokachi District, Hokkaido, Japan from May to October, 2018. Raccoons have been reported in Memuro since 2014. We photographed red foxes, raccoons, raccoon dogs (Nyctereutes viverrinus albus), domestic cats (Felis catus), weasels, murids, Eurasian red squirrels (Sciurus vulgaris), sika deer (Cervus nippon), bats, and birds. Proportions of animal species photographed significantly differed among seasons. Red foxes, raccoons, raccoon dogs, domestic cats, and murids consumed fox bait. Proportions of animals consuming fox bait were significantly differed among seasons. In summer and autumn, raccoons frequently appeared at baiting sites and consumed fox bait. We recommend removing raccoons from the area, before baiting campaign.

How to cite this article: Arisawa H., Uraguchi K., Kouguchi H., Oshida T. 2020. Note on consumption of fox bait by alien raccoons in eastern Hokkaido, Japan // Russian J. Theriol. Vol.19. No.2. P.178-182. doi: 10.15298/rusjtheriol.19.2.08.

KEY WORDS: alien species, alveolar echinococcosis, red fox, Procyon lotor, Vulpes vulpes.

Hiiragi Arisawa [arisawa2017@gmail.com] \& Tatsuo Oshida, [oshidata@obihiro.ac.jp],Laboratory of Wildlife Biology, Obihiro University of Agriculture and Veterinary Medicine, Inada, Obihiro 080-8555, Japan; Kohji Uraguchi [ura@iph. pref.hokkaido.jp] \& Hirokazu Kouguchi [kouguchi@iph.pref.hokkaido.jp], Department of Infectious Disease, Hokkaido Institute of Public Health, Sapporo 060-0819, Japan.

\section{Заметки о поедании приманки для лис интродуцированными енотами на востоке Хоккайдо, Япония}

\author{
Х. Арисава, К. Урагучи, Х. Когучи, Т. Ошида*
}

РЕЗЮМЕ. Альвеолярный эхинококкоз представляет собой зооноз, вызванный ленточным червем, Echinococcus multilocularis. Обыкновенная лисица (Vulpes vulpes) является его основным хозяином. Эффективное снижение распространенности E. multilocularis является результатом травления лисиц антигельминтным празиквантелом. В последнее время увеличивается численность интродуцированных енотов-полоскунов (Procyon lotor) на острове Хоккайдо, Япония. Если еноты часто поедают приманку для лис, кампания по дегельминтизации обыкновенной лисицы может быть неэффективна. В период с мая по октябрь 2018 с помощью фотоловушек мы исследовали сезонное потребление енотами приманки для лис в Мемуро, округ Токачи, Хоккайдо, Япония. Еноты отмечены в Мемуро с 2014 года. Мы фотографировали лисиц, енотов, енотовидных собак (Nyctereutes viverrinus albus), домашних кошек (Felis catus), куньих, мышевидных грызунов, белок (Sciurus vulgaris), пятнистых оленей (Cervus nippon), летучих мышей и птиц. Соотношение сфотографированных видов животных значительно различалось между сезонами. Лисицы, еноты, енотовидные собаки, домашние кошки и мышевидные грызуны поедали приманку для лис. Соотношение видов животных, потребляющих приманку для лис, значительно различалось между сезонами. Летом и осенью еноты часто появлялись на местах травления и поедали приманку для лис. Рекомендуется удалять енотов из зоны работ перед началом кампании по дегельминтизации.

КЛЮЧЕВЫЕ СЛОВА: чужеродные виды, альвеолярный эхинококкоз, обыкновенная лисица, Procyon lotor, Vulpes vulpes.

* Corresponding author 


\section{Introduction}

In Japan, the red fox (Vulpes vulpes) is common on Hokkaido, Honshu, Shikoku, and Kyushu islands (Uraguchi, 2015). On Hokkaido Island, it carries the zoonotic disease, alveolar echinococcosis, caused by the metacestode stage of Echinococcus multilocularis (Yamashita \& Kamiya, 1997). This disease is widespread in the Northern Hemisphere (Soulsbury et al., 2010). In Hokkaido, the red fox is the principle definitive host, with rodents, such as the red-backed vole (Myodes rufocanus), as main intermediate hosts (Tsukada, 2005). Infection rate of red foxes in Hokkaido is around 40\% (Takahashi et al., 2005; Nonaka et al., 2006). Each year, 15-20 persons are newly diagnosed with alveolar echinococcosis (Hokkaido Government, 2015). Therefore, it is important to prevent $E$. multilocularis infection in red foxes. To decrease E. multilocularis prevalence in red foxes, baiting foxes with the anthelmintic praziquantel is effective (Hegglin et al., 2003; Romig et al., 2007; König et al., 2019). In Hokkaido, this baiting was carried out in Koshimizu (Tsukada et al., 2002), Nemuro (Takahashi et al., 2002, 2013), Otaru (Nonaka et al., 2006; Inoue et al., 2007), and Kutchan (Hokkaido Government, 2007).
The baiting campaign reduced rate of $E$. multilocularis infection in red foxes (Tsukada, 2005), but, long-term baiting is necessary to maintain the effect (Hokkaido Government, 2007).

Takyu et al. (2013) reported that fox bait were often consumed by other animals, such as domestic dogs $(\mathrm{Ca}$ nis lupus familiaris) and cats (Felis catus). At present, raccoons (Procyon lotor), which were introduced into Hokkaido around 40 years ago (Ikeda, 2015), are rapidly increasing. Since raccoons are omnivorous, larger, and probably stronger than red fox (Ikeda, 2015), they may outcompete foxes for fox bait. If raccoons frequently consume fox bait, the baiting campaign on red foxes may not be effective.

In Tokachi District of Hokkaido (Fig. 1), population of red foxes seems to be stable, but raccoons have been rapidly increased since 2016 (Fig. 2) (Hokkaido Government, 2019). Therefore, this area could be suitable to examine influence of raccoons on the campaign for baiting red foxes. We used camera traps, to show that raccoons consume fox bait in the agricultural area of Memuro, Tokachi District, Hokkaido (Fig. 1), an area where raccoons have been reported since 2014 (Yamaguchi, 2015).

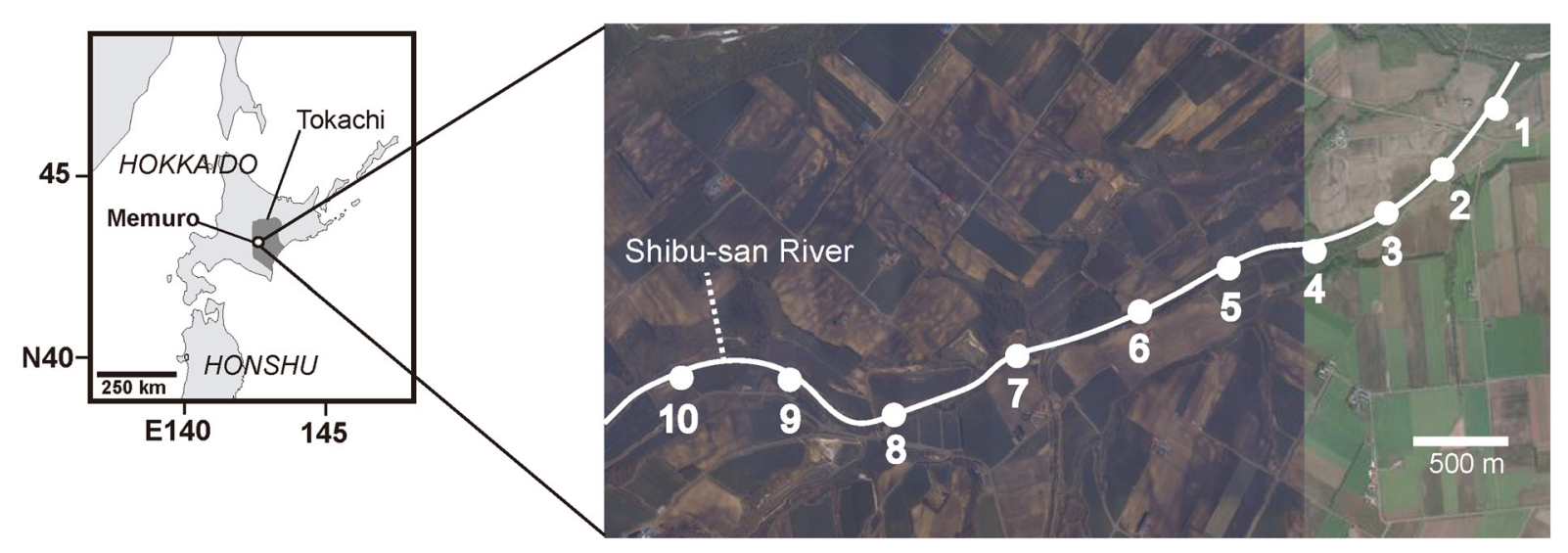

Fig. 1. Study sites in Memuro, Tokachi District, Hokkaido, Japan. Numbered circles indicate location of camera traps. This map is based on an aerial photograph published by Geospatial Information Authority of Japan.

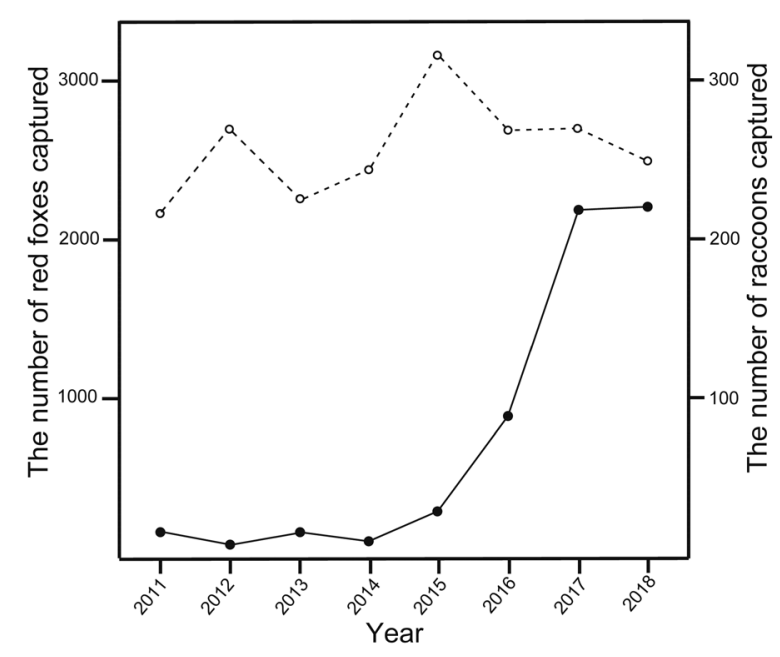

Fig. 2. The number of raccoons (solid circles with solid lines; left bar) and red foxes (open circles with dotted lines) captured from 2011 to 2018 in Tokachi District, Hokkaido, Japan (Hokkaido Government, 2019). 


\section{Material and methods}

\section{Study area}

We conducted this study in the agricultural area of Memuro, Tokachi District in eastern Hokkaido, Japan $\left(42^{\circ} 53^{\prime} \mathrm{N}, 142^{\circ} 59^{\prime} \mathrm{E}\right.$, see Fig 1). Average temperature and precipitation are $6.1^{\circ} \mathrm{C}$ and $957.3 \mathrm{~mm}$, respectively (Japan Meteorological Agency, http://www.jma.go.Jp/ $\mathrm{jma} / \mathrm{menu} / \mathrm{report}$.html). We surveyed the riparian forest along the Shibu-san River (Fig. 1), because both red fox (personal communications with local farmers) and raccoon (Yamaguchi, 2015) were present. A transect line approximately $5.0 \mathrm{~km}$ along the Shibu-san River was established following Takyu et al. (2013). Ten baiting sites were established at 400-500 m intervals (Fig. 1).

\section{Preparation of fox bait}

Following Takahashi et al. (2010), we made bait for red foxes. Each bait was $15 \mathrm{~g}(44 \times 44 \times 15 \mathrm{~mm})$ and made of palm oil, sunflower oil, and fish meal. Since purpose of this study was not to treat animals for E. multilocularis, we did not add the anthelmintic praziquantel.

\section{Baiting and camera trapping}

Following Takyu et al. (2013) and Ishida et al. (2014), we put five bait on a wooden board (450 $\times$ $300 \times 2.5 \mathrm{~mm})$ on the ground and set one camera trap (FieldnoteDS6010, Marifu Co. Ltd., Japan) about $3 \mathrm{~m}$ from the board. Camera traps were fixed on tree trunks at $150-170 \mathrm{~cm}$ in height. From May to October 2018, we repeated a cycle of surveying for seven straight days with fox bait and cameras and pausing 14-21 straight days. We checked photographs and number of bait consumed at each site daily, replacing consumed bait with fresh bait. We recorded number of removed bait.

\section{Data analyses}

We counted number of photographs of each animal species taken by camera trap. As it was difficult us to identify individuals, we counted the total number of photographs taken by each camera, but not number of individuals. To avoid counting multiple photographs of the same individual, we followed Iwashita et al. (2015) by not counting subsequent photographs made within $10 \mathrm{~min}$, unless it was of a different species. We compared number of photographs among animal species among three seasons: spring (May and June), summer (July and August), and autumn (September and October) with a Chi-squared test. We also calculated disappearance rates of fox bait for each season. If at least one bait disappeared at the baiting site, we counted that as one disappearance and then we calculated the disappearance rate as follows:

bate disappearance rate $=$ the total number of baiting sites found bait disappearance for each season / the total number of baiting sites for each season (10 sites $\times$ 7 days $\times 2$ months $=140$ sites $) \times 100 \%$.

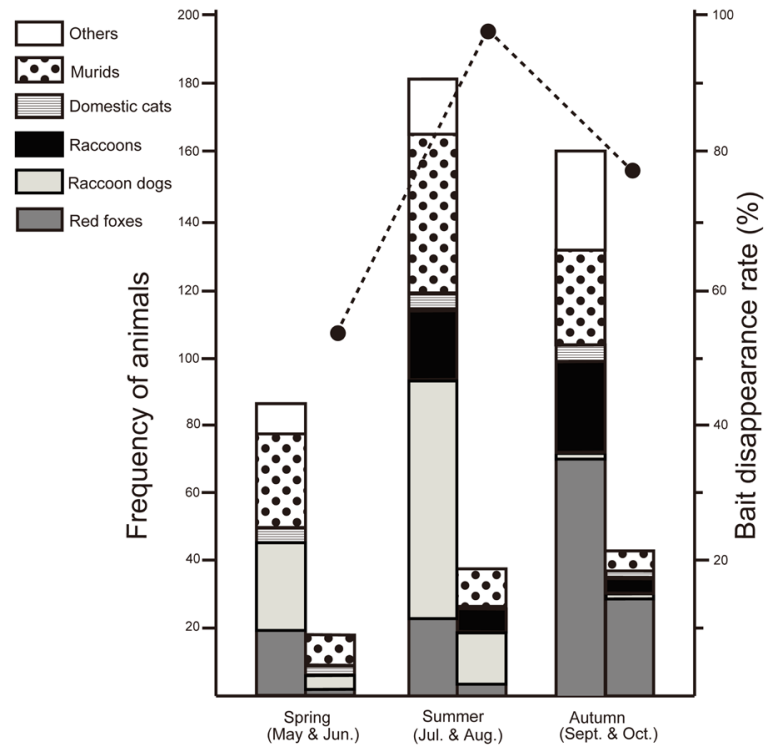

Fig. 3. Seasonal change in animals photographed by cameratraps (left bars) and detected as a consumer of fox bait (right bars) from May to October, 2018 in Memuro, Tokachi District, Hokkaido, Japan. Dotted line is seasonal change in bait disappearance rate.

Following Ishida et al. (2014), we determined whether captured species were consumers of fox bait by analyzing sequence photographs of each individual.

If number of bait had clearly decreased after the animal left the baiting site, we considered the individual a consumer and counted the number (frequency) of consumption by each animal species.

\section{Results}

In a total of 42 trapping days, we took 424 photos: 112 of red foxes, 44 of raccoons, 96 of raccoon dogs (Nyctereutes viverrinus albus), 16 of domestic cats (Felis catus), 9 of weasels, 102 of murids, 22 of Eurasian red squirrels (Sciurus vulgaris), 10 of sika deer (Cervus nippon), 6 of bats, and 7 of birds. Unfortunately, it was difficult to precisely identify species of weasels, murids, bats, and birds. When red foxes, raccoons, raccoon dogs, domestic cats, and murids were photographed, some bait disappeared. Thus, we categorized animals into six groups: red foxes, raccoons, raccoon dogs, domestic cats, murids, and others (Eurasian red squirrels, weasels, bats, sika deer, and birds). We photographed red foxes and murids at nine baiting sites, raccoons at seven sites, and raccoon dogs and domestic cats at five sites. Proportions of animal species photographed by camera traps were significantly different between spring and summer $\left(\chi^{2}=\right.$ $18.08, d f=5, p<0.01)$ and between summer and autumn $\left(\chi^{2}=95.40, d f=5, p<0.001\right)$ (Fig. 3). Frequency of red fox photographed in spring $(n=20)$ was similar to that in summer $(n=24)$, but radically increased in autumn 
$(n=68)$. Raccoons were not photographed in spring, but numbers were similar in summer $(n=20)$ and autumn $(n=24)$. Frequencies of raccoon dog varied with seasons ( $n=24$ in spring, $n=71$ in summer, and $n=1$ in autumn). Domestic cats appeared all three seasons $(n=5$ in spring and summer, and $n=6$ in autumn). Murids were present in spring $(n=29)$ and autumn $(n=27)$, but most frequent in summer $(n=46)$. Total fox bait disappearance rate was $77.4 \%$. Seasonal disappearance rates were $55.4 \%$ in spring, $98.7 \%$ in summer, and $78.0 \%$ in autumn (Fig. 3 ). Proportions of animals consuming fox bait significantly differed between spring and summer $\left(\chi^{2}=10.04, d f=4\right.$, $p<0.05)$ and between summer and autumn $\left(\chi^{2}=35.39\right.$, $d f=4, p<0.001$ ) (Fig. 3). Frequency of bait consumption by red foxes in spring $(n=2)$ was similar to that in summer $(n=5)$, but radically increased in autumn $(n=$ 29). Raccoons consumed fox bait in summer $(n=8)$ and autumn $(n=4)$. Raccoon dogs varied with seasons $(n=$ 5 in spring, $n=16$ in summer, and $n=1$ in autumn). Domestic cats consumed 2 fox bait in two seasons $(n=2$ in spring and $n=1$ in autumn). Murids consumed fox bait in spring $(n=9)$, summer $(n=12)$, and autumn $(n=5)$.

\section{Discussion}

Red foxes were most common at nine sites and consumed fox bait, suggesting effectiveness of baiting campaigns. Raccoons, however, were commonly photographed at seven baiting sites and also consumed fox bait. Therefore, raccoons may prevent red foxes from eating bait in Hokkaido because of indirect competition between the two species. Since raccoons are not a principle definitive host of $E$. multilocularis (e.g., Asakawa et al., 2000), it is not useful for human health to bait raccoons. When raccoons frequently consume fox bait, baiting campaign may not be effective on red fox populations in Hokkaido.

Red foxes were most frequently captured by camera traps in autumn (Fig. 3). In studies conducted in the agricultural areas of Obihiro in the Tokachi District of Hokkaido, Takyu et al. (2013) report red foxes being most frequently photographed in spring, and Ishida et al. (2014) show red foxes are frequently photographed from June to July. Our results in the riparian forest were quite different from those. In the Tokachi District, the riparian forests are thought to be corridors for wild mammals (Yoshioka \& Yanagawa, 2008). Therefore, the forests would be more frequently used by wild mammals. This may explain the difference from previous studies conducted in non-riparian forests. Further study should examine the relationship between habitats and animals captured by camera-traps.

Raccoon dogs were also frequently photographed. A protoscolex of $E$. multilocularis attaches to the small intestinal mucosa of raccoon dogs, but unlike red foxes, the protoscolex does not reach complete maturity in Hokkaido (Oku, 2010). In Europe, however, introduced raccoon dogs are regarded as a definitive host for E. multilocularis (Schwarz et al., 2011). Therefore, baiting raccoon dogs would be effective for prevention of alveolar echinococcosis. Murids were second most frequently captured by camera-traps and consumed many bait. Consumption of fox bait by murids has not been studied. Judging from the number of consumed bait, the influence of murids on baiting campaign should be considered in future studies.

In the present study, we first found that introduced raccoons frequently consumed fox bait in Hokkaido. Therefore, we recommend removing raccoons from the area, before baiting campaign. This will ensure effective treatment of red foxes with the anthelmintic praziquantel.

ACKNOWLEDGEMENTS. We thank E. Yamaguchi (Hokkaido Research Organization) and Y. Asari and T. Akasaka (Obihiro University of Agriculture and Veterinary Medicine) for their helpful information and comments concerning this study. We thank C.L. Bridgman for her critical reading of the manuscript.

\section{References}

Asakawa M., Matoba Y., Yamada D. \& Kamiyama T. 2000. Review of the parasitological state of feral raccoons captured in Nopporo National Park and its proximity, Hokkaido // Journal of Rakuno Gakuen University. Vol.25. P.1-8 [in Japanese with English summary].

Hegglin D., Ward P.I. \& Deplazes P. 2003. Anthelmintic bating of foxes against urban contamination with Echinococcus multilocularis // Emerging Infection Diseases. Vol.9. P.1266-1272.

Hokkaido Government. 2007. [A Guideline Using Anthelmintics on Red Foxes: Measures against Echinococcosis]. Sapporo: Hokkaido Government. 15 p. [in Japanese].

Hokkaido Government. 2015. [Q \& A to avoid suffering from echinococcosis]. Available at http://www.pref.hokkaido. lg.jp/hf/kth/ekinoWeb20150402.pdf. Accessed 14 August 2019. [In Japanese].

Hokkaido Government. 2019. [Statistics on wildlife in Hokkaido Prefecture, Japan]. Available at http://www.pref. hokkaido.lg.jp/ks/skn/toukei/tyozu.htm. Accessed 21 April 2020. [In Japanese].

Ikeda T. 2015. Procyon lotor (Linnaeus, 1758) // Ohdachi S.D., Iwasa M.A., Ishibashi Y., Fukui D. \& Saitoh T. (eds.). The Wild Mammals of Japan. 2nd ed. Kyoto: Shoukadoh Book Seller. P.232-233.

Inoue T., Nonaka N., Kanai Y., Iwaki T., Kamiya M. \& Oku Y. 2007. The use of tetracycline in anthelmintic baits to assess baiting rate and drug efficacy against Echinococcus multilocularis in foxes // Veterinary Parasitology. Vol.150. P.88-96.

Ishida A., Takahashi K., Uraguchi K. \& Oshida T. 2014. Environmental factors for efficiently baiting red foxes in agricultural areas in eastern Hokkaido, Japan // Mammal Study. Vol.39. P.167-172.

Iwashita A., Ogawa H. \& Ando M. 2015. Effectiveness of camera trap data as relative abundance index of the raccoon (Procyon lotor) // Journal of Agricultural Science, Tokyo University of Agriculture. Vol.60. P.69-76 [in Japanese with English summary]. 
König A., Romig T. \& Holzhofer E. 2019. Effective longterm control of Echinococcus multilocularis in a mixed rural-urban area in southern Germany // PLOS ONE. Vol.14 (4): e0214993.

Nonaka N., Kamiya M. \& Oku Y. 2006. Towards the control of Echinococcus multilocularis in the definitive host in Japan // Parasitology International. Vol.55. P.S263-S266.

Oku Y. 2010. [Echinococcosis]. Tokyo: Japan Livestock Industry Association. 19 p. [in Japanese].

Romig T., Bilger B., Dinkel A., Meril M., Thoma D., Will R., Mackenstedt U. \& Lucius R. 2007. Impact of praziquantel baiting on intestinal helminths of foxes in southwestern Germany // Helminthologia. Vol.44. P.137-144.

Schwarz S., Sutor A., Staubach C., Mattis R., Tackmann K. \& Conraths F.J. 2011. Estimated prevalence of Echinococcus multilocularis in raccoon dogs Nyctereutes procyonoides in northern Brandenburg, Germany // Current Zoology. Vol.57. P.655-661.

Soulsbury C.D., Baker P.J., Iossa G. \& Harris S. 2010. Red foxes (Vulpes vulpes) // Gehrt S.D., Riley S.P.D. \& Cypher B.L. (eds.). Urban Carnivores: Ecology, Conflict, and Conservation. Baltimore: Johns Hopkins University Press. P.62-75.

Takahashi K., Uraguchi K., Romig T., Hatakeyama H. \& Tamura M. 2002. [Preliminary report on Echinococcus multilocularis control by fox bating with paraziquantel] // Report of Hokkaido Institute of Public Health. Vol.52. P.61-63 [in Japanese].

Takahashi K., Uraguchi K. \& Kudo S. 2005. The epidemiological status of Echinococcus multilocularis in animals in Hokkaido, Japan // Mammal Study. Vol.30. Suppl. P.101-105

Takahashi K., Uraguchi K., Abe S. \& Hirakawa, H. 2010. [Making acceptable bait by red foxes] // Report of Hokkaido Institute of Public Health. Vol.60. P.81-82 [in Japanese].
Takahashi K., Uraguchi K., Hatakeyama H., Giraudoux P. \& Romig T. 2013. Efficacy of anthelmintic baiting of foxes against Echinococcus multilocularis in northern Japan // Veterinary Parasitology. Vol.198. P.122-126.

Tsukada H., Hamazaki K., Ganzorig S., Iwaki T., Konno K., Lagapa J., Matsuno K., Ono A., Shimizu M., Sakai H., Morishima Y., Nonaka N., Oku Y. \& Kamiya M. 2002. Potential remedy against Echinococcus multilocularis in wild red foxes using baits with anthelmintic distributed around fox breeding dens in Hokkaido, Japan // Parasitology. Vol.125. P.119-129.

Tsukada H. 2005. [Foraging behavior of red foxes and echinococcosis] // Honyurui Kagaku [Mammalian Science]. Vol.45. P.91-98 [in Japanese].

Takyu M., Takahashi K., Uraguchi K \& Oshida T. 2013. Fox bait consumption and camera trapping in agricultural areas in eastern Hokkaido, Japan // Mammal Study. Vol.38. P. 57-60.

Uraguchi K. 2015. Vulpes vulpes (Linnaeus, 1758) // Ohdachi S.D., Iwasa M.A., Ishibashi Y., Fukui D. \& Saitoh T. (eds.). The Wild Mammals of Japan. 2nd ed. Kyoto: Shoukadoh Book Seller. P.222-223.

Yamaguchi E. 2015. Environmental Risk Factors Associated with Infection in Raccoons. PhD Thesis. Morioka: The United Graduate School of Agricultural Sciences, Iwate University. 105 p. [in Japanese with English summary].

Yamashita J. \& Kamiya M. 1997. [Echinococcus: Its Characters and Preventives]. Sapporo: Hokkaido University Press. 274 p. [in Japanese].

Yoshioka A. \& Yanagawa Y. 2008. Utilization of riparian forests and windbreak forests by mammals in the Tokachi District of Hokkaido // Research Bulletin of Obihiro University of Agriculture of Veterinary Medicine. Vol.29. P.66-73 [in Japanese with English summary]. 